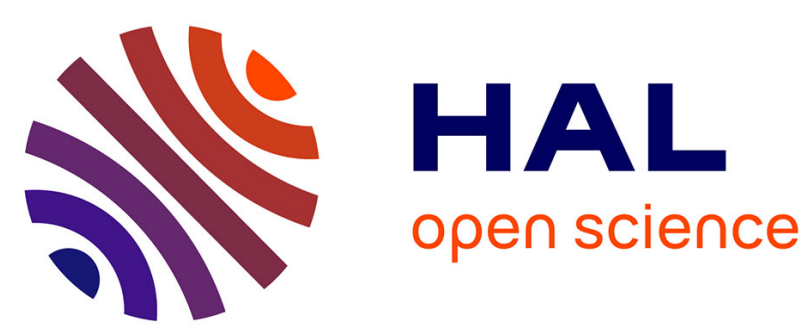

\title{
Experimental assessment of a PCM to air heat exchanger storage system for building ventilation application
}

Matthieu Labat, Joseph Virgone, Damien David, Frédéric Kuznik

\section{To cite this version:}

Matthieu Labat, Joseph Virgone, Damien David, Frédéric Kuznik. Experimental assessment of a PCM to air heat exchanger storage system for building ventilation application. Applied Thermal Engineering, 2014, 66, pp.375-382. 10.1016/j.applthermaleng.2014.02.025 . hal-00985318

\section{HAL Id: hal-00985318 https://hal.science/hal-00985318}

Submitted on 28 May 2014

HAL is a multi-disciplinary open access archive for the deposit and dissemination of scientific research documents, whether they are published or not. The documents may come from teaching and research institutions in France or abroad, or from public or private research centers.
L'archive ouverte pluridisciplinaire HAL, est destinée au dépôt et à la diffusion de documents scientifiques de niveau recherche, publiés ou non, émanant des établissements d'enseignement et de recherche français ou étrangers, des laboratoires publics ou privés. 


\section{APPLIED THERMAL ENGINEERING Manuscript Draft}

\section{TITLE: Experimental assessment of a PCM to air heat exchanger storage system for building ventilation application}

ARTICLE TYPE: Research paper

\section{ABSTRACT}

This paper presents a heat exchanger prototype containing PCM material designed to provide a $1 \mathrm{~kW}$ heating power during 2 hours (i.e. energy storage of $2 \mathrm{kWh}$ ). The exchanger is tested in a closed-loop wind tunnel, used to provide constant airflow rates with temperature changes selected so that the PCM is allowed to melt, then to solidify. Temperature and air velocity measurements are achieved for eight airflow rates and the heating power is estimated. The second objective of this work is to provide detailed results suitable with the validation of numerical models. Therefore, the geometry of the exchanger is detailed and the uncertainty associated with the heating power measurement is given. Results show that enough energy is stored in the exchanger, yet the heating power is lower than $1 \mathrm{~kW}$ before 2 hours because of the use of a of constant airflow rate during the tests. On the other hand, the global behaviour of the heat exchanger is rather simple, which gives confidence in using a simplified approach in further work and help with optimising the current prototype.

\section{KEYWORDS}

Heat exchanger, PCM, experimentation, heat release, dimensionless correlation 


\section{HIGHLIGHTS}

- The objective is to withdraw the heat pump from the grid during the two hours of electrical peak power

- Design of a new heat exchanger with PCM integrated in a air ventilation system

- Laboratory experiment to analyze the heat exchanger efficiency

- Dimensionless analyses to have general conclusions on the system efficiency 


\section{COVER LETTER}

\section{Dear Editor of Applied Thermal Engineering}

The paper has been revised based on the reviewers comments. A list of answers to the reviewers is also enclosed. I feel that the quality of the paper has been enhanced by our revision. Then, I hope that this new submission will fit to the publication requirements of Applied Thermal Engineering.

I look forward to hearing from you.

Best regards,

Joseph VIRGONE

Professor of Université Lyon1 


\title{
Experimental assessment of a PCM to air heat exchanger storage system for building ventilation application
}

\author{
Labat M. ${ }^{1,3}$, Virgone J. ${ }^{*, 1,2}$, David D. ${ }^{1,2}$, Kuznik $F^{1,3}$
}

\author{
${ }^{1}$ Université de Lyon, CNRS \\ 2 Université Lyon 1, CETHIL UMR 5008, F-69622, Villeurbanne, France \\ ${ }^{3}$ INSA-Lyon, CETHIL UMR5008, F-69621, Villeurbanne, France \\ (*) Correspondent author, joseph.virgone@insa-lyon.fr
}

Bât. Sadi Carnot, 9 rue de la physique, 69621 Villeurbanne Cedex, France

Tel. (33) 0472436225

\section{NOMENCLATURE}

$\begin{array}{lll}\mathrm{C}_{\mathrm{P}} & \text { heat capacity } & \mathrm{kJ} \cdot \mathrm{kg}^{-1} \cdot \mathrm{K}^{-1} \\ \mathrm{e} & \text { thickness } & \mathrm{m} \\ \mathrm{Fo} & \text { Fourier number } & - \\ \mathrm{h}_{\mathrm{c}} & \text { convective heat transfer coefficient } & \mathrm{W} \cdot \mathrm{m}^{-2} \cdot \mathrm{K}^{-1} \\ \mathrm{p} & \text { pressure } & \mathrm{Pa} \\ \mathrm{P} & \text { heating power } & \mathrm{W} \\ \mathrm{Q}_{\mathrm{V}} & \text { airflow rate } & \mathrm{m}^{3} \cdot \mathrm{s}^{-1} \\ \mathrm{~S} & \text { cross-section } & \mathrm{m}^{2} \\ \mathrm{St} & \text { Stanton number } & - \\ \mathrm{T} & \text { temperature } & { }^{\circ} \mathrm{C} \\ \mathrm{t}_{\mathrm{r}} & \text { time for heat release } & \mathrm{S} \\ \mathrm{u} & \text { uncertainty } & \\ \mathrm{v} & \text { velocity } & \mathrm{m} \cdot \mathrm{s}^{-1}\end{array}$

Greek symbols

$\begin{array}{lll}\rho & \text { density } & \mathrm{kg} \cdot \mathrm{m}^{-3} \\ \lambda & \text { thermal conductivity } & \mathrm{W} \cdot \mathrm{m}^{-1} \cdot \mathrm{K}^{-1} \\ \sigma & \text { standard deviation } & \\ \Delta & \text { difference } & \end{array}$

Subscripts

A air

HVAC Heating Ventilation Air Conditioning

Meas measured

PCM phase change material

Sim simulated

Constants

$A_{1}, A_{2}, A_{3} \quad$ fitting coefficients in equation (7)

$\mathrm{C}_{\mathrm{P}, \mathrm{A}} \quad$ heat capacity of air $=1004 \mathrm{~J} \cdot \mathrm{kg}^{-1} \cdot \mathrm{K}^{-1}$

$\mathrm{C}, \mathrm{n} \quad$ fitting coefficients in equation (5)

$\mathrm{K}$ ratio of the measured velocity to the average velocity $(=0.89)$

Abbreviations

CFD Computational Fluid Dynamics

PCM Phase Change Material 


\section{INTRODUCTION}

Nowadays, thermal energy storage systems (TESS) are essential to rationalize the energy management and the use of environmental energy potential. Concepts including phase change materials (PCM) are technically mature for building applications and innovations [1-11]. Most of the concepts are dedicated to heating purposes, with either a passive or an active point of view. On the other hand, studies reviewed in [12] aim at reducing the cooling loads and some examples are presented in [13-15].

In this study, the general idea is to use a TESS to influence the distribution of the electrical demand for a typical dwelling, heated by an electrical system. In several countries, the electricity rate is significantly varying during the day, along with the energy demand. Therefore, such system presents an economical interest. In our study, the system is a heat exchanger containing PCM and integrated in the ventilation network of the building. It is designed to be function with the electrical heating system, for example a heat pump, and used to store energy when the electricity rate (or the whole electricity demand) is low. When the electricity rate increases, the heating system is shut down and heat is released from the exchanger. This general concept is also known as electrical peak loads shaving and is detailed in [16]. The concept is:

- Phase (a): storage of heat process is carried during energy off-peak period. The heating system runs and the heated air is passing through the heat exchanger. The material phase is changing from solid to liquid and required to absorb heat from the airflow.

- Phase (b): release of heat process is carried during energy peak period. The heating system stops and the cold air is passing through the heat exchanger. The material phase is changing from liquid to solid and required to release heat to the airflow.

Sufficient energy has to be stored in order to replace the use of the heating system, that is to say, to maintain comfortable indoor conditions. Of course, this requirement depends strongly on the building of interest. However, this study does not focus neither on a specific building nor a ventilation network, but aims at verifying the feasibility of this general concept. In our study, the specific requirements are the release of a heating power of $1 \mathrm{~kW}$ during 2 hours (i.e. $2 \mathrm{kWh}$ ). Both, the latent and sensible heats are used for energy storage/release in order to decrease the system size.

In the paper, a heat exchanger built at our laboratory is presented. It is tested in a wind-tunnel facility so its heating power is measured under dynamic conditions representative of its integration in a real ventilation network. The main objective is to understand how the system behaves and to verify the required heating power. The second objective of this work is to provide detailed results suitable with the validation of numerical models. This need is clearly mentioned in [17], where the authors collected data from several experiments and underlined the lack of detailed measurements.

The first section of this paper deals with the prototype built at our laboratory and the PCM material. In the second section, the experimental facility and the earliest characterisation tests are presented. Finally, the heating power and the cumulative energy are presented and discussed.

\section{PROTOTYPE DESIGN METHODOLOGY}

In the first part of this section, the thermal properties of the PCM are described. In the second and third parts, the design of the PCM heat exchanger is explained.

\subsection{PCM properties}

The selected material was paraffin based. Its commercial name is Microtek 37D1 and its thermal properties

\footnotetext{
${ }^{1}$ http://www.microteklabs.com/pdfs/MPCM-37D\%20Product\%20Data\%20Sheet.pdf
} 
were measured in our laboratory. Results are presented in Table 1. The effective specific heat was measured on a $0.0086 \mathrm{~g}$ sample, using the DSC method (Differential Scanning Calorimeter) at a $1^{\circ} \mathrm{C} \cdot \mathrm{min}^{-1}$ heating rate (see figure 1). During the melting, the phase change effects are observed when the temperature is growing from 25 to $35^{\circ} \mathrm{C}$. A heat flux peak occurs at $34.5^{\circ} \mathrm{C}$.

During the solidification, the phase change effects are observed between $33^{\circ} \mathrm{C}$ and $22 \mathrm{C}$. The heat flux peak occurs at $31^{\circ} \mathrm{C}$ at the secondary peak is observed at $24^{\circ} \mathrm{C}$. Still, the values of the latent heat obtained with both experiments are in good agreement (3\%).

\section{Table 1: Thermal properties of the material}

\begin{tabular}{lll}
\hline & Solid state & Liquid state \\
\hline Density $\left(\mathrm{kg} \cdot \mathrm{m}^{-3}\right)$ & 870 & 779 \\
Thermal conductivity $\left(\mathrm{W} \cdot \mathrm{m}^{-1} \cdot \mathrm{K}^{-1}\right)$ & 0.24 & 0.18 \\
Heat capacity $\left(\mathrm{kJ} \cdot \mathrm{kg}^{-1} \cdot \mathrm{K}^{-1}\right)$ & $2.398(10 \mathrm{C})$ & $2.206(33 \mathrm{C})$ \\
Melting heat $\left(\mathrm{kJ} \cdot \mathrm{kg}^{-1}\right)$ & 222 &
\end{tabular}

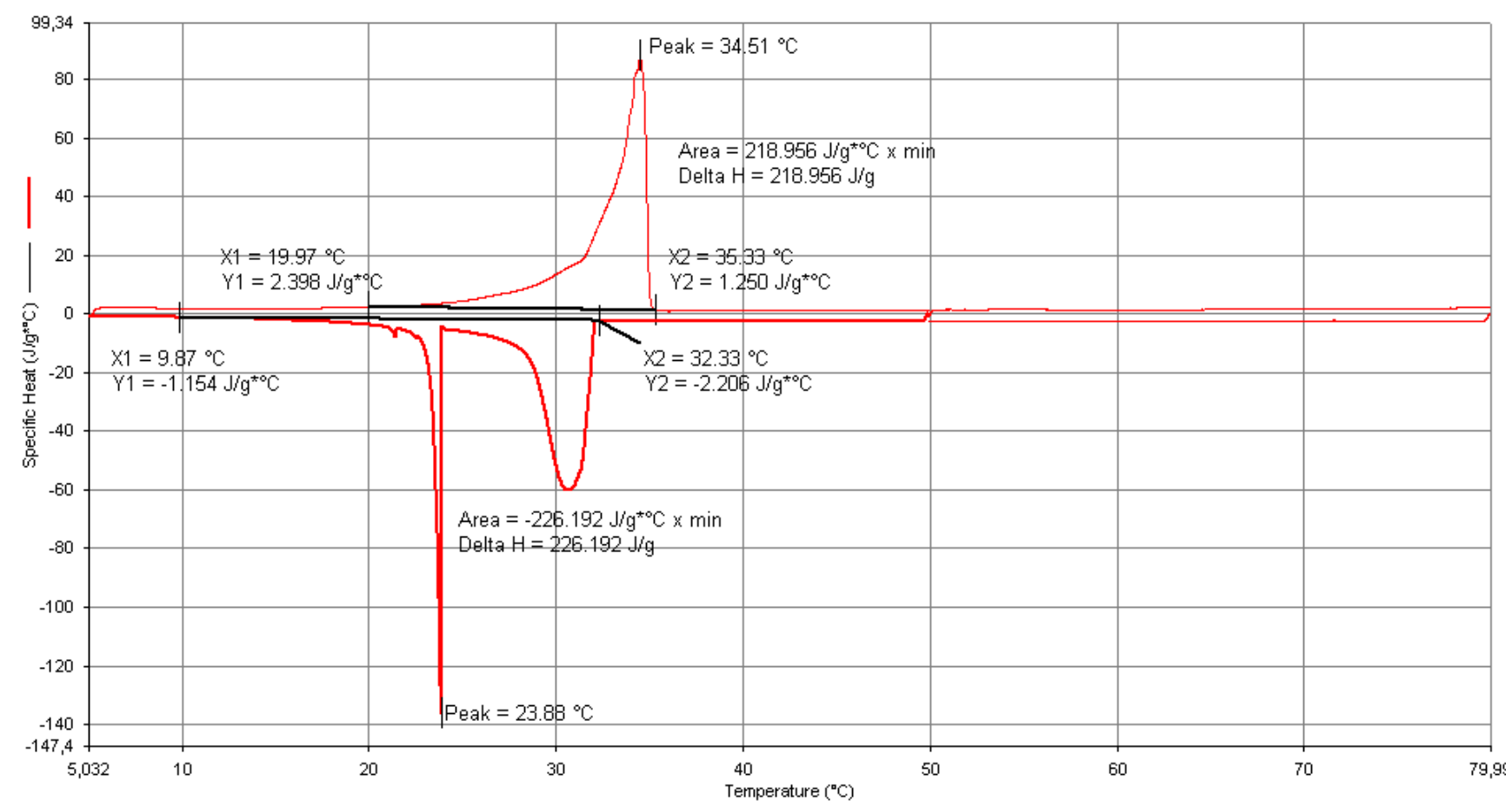

Figure 1: Equivalent heat capacity of the Microtek 37 from DSC measurement

\subsection{Design of the PCM containers}

The PCM is distributed into 34 plane-parallel aluminium containers (dimensions: $0.018 \mathrm{~m} \times 0.200 \mathrm{~m} \times$ $1.000 \mathrm{~m})$. Each container was made of two identical cavities filled with PCM. Each cavity was sealed with aluminium sidings $(0.016 \mathrm{~m} \times 0.016 \mathrm{~m} \times 0.048 \mathrm{~m}$. The cavities were partially filled and air vents were placed at the top of the aluminium sides to prevent PCM leakages due to the density changes (Figure 2). The total mass 
of empty containers was $18.53 \mathrm{~kg}$, and the total mass of PCM was measured at $27.88 \mathrm{~kg}$.

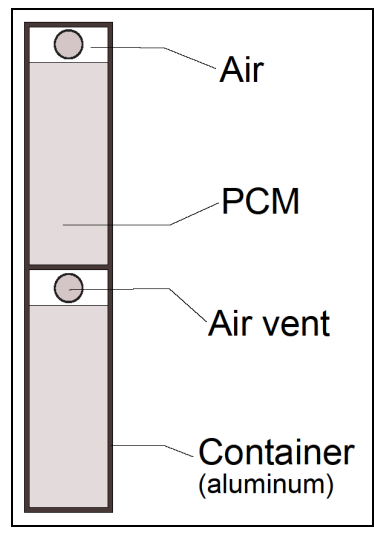

Figure 2: Scheme of a single container filled with PCM

\subsection{Design of the heat exchanger}

The heat exchanger was made of the 34 containers and cooling fins (the total mass of the cooling fins was $4.69 \mathrm{~kg})$. Containers were pilled up by two, which results in 17 blocks $(0.200 \mathrm{~m} \times 0.018 \mathrm{~m} \times 1.000 \mathrm{~m})$. The blocks were separated by fins of identical cross-sections (see Figure 3 ). The fins awere designed so that the air layer which is separating two blocks is divided into 50 channels $(0.004 \mathrm{~m} \times 0.018 \mathrm{~m} \times 1.000 \mathrm{~m})$. The whole assembly was surrounded with aluminium plates and the overall cross-section was $0.200 \mathrm{~m} \times 0.630 \mathrm{~m}$. Finally, the exchanger was insulated using a $0.040 \mathrm{~m}$ thick layer of polystyrene and mineral wool (i.e. thermal resistance of about $\left.1 \mathrm{~m}^{2} . \mathrm{K} / \mathrm{W}\right)$.

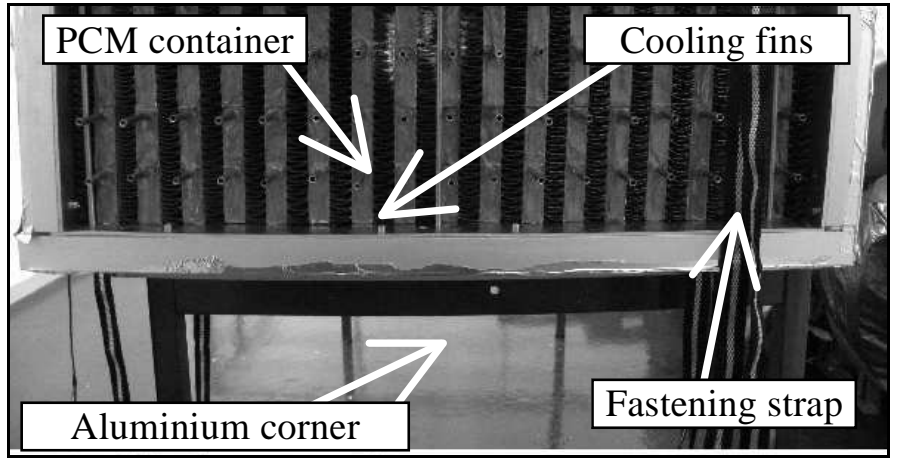

Figure 3 : External view the heat exchanger front

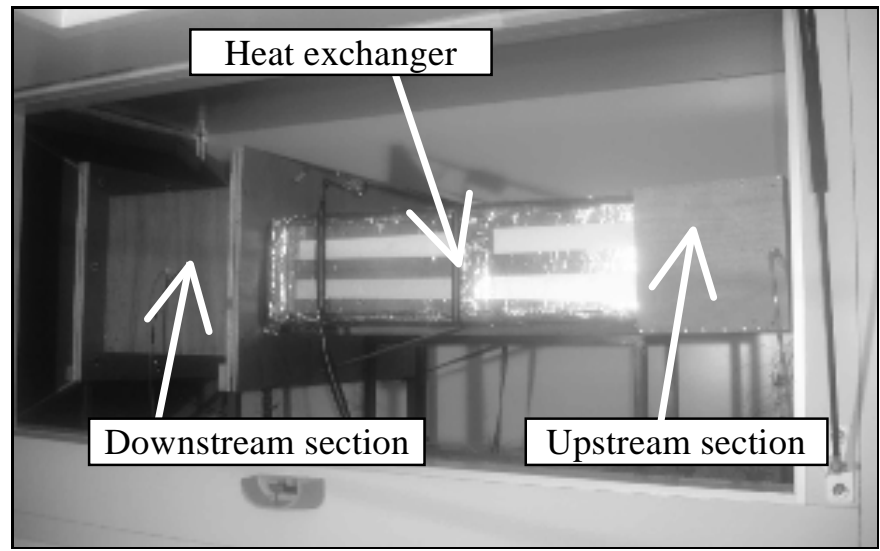

Figure 4 : Picture of the heat exchanger installed in the experimental set-up 


\section{EXPERIMENTAL SET-UP AND CHARACTERISATION TESTS}

The main objective is to estimate the heating power of the heat exchanger; it can be evaluated with:

$$
P=\rho_{A}(T) \cdot \dot{Q}_{V} \cdot C_{P, A} \cdot\left(\Delta T_{A}\right)
$$

Where the air density $\rho_{A}$ is given by:

$$
\rho_{A}=1.293 \cdot \frac{273.15}{T_{A}(K)}
$$

The uncertainty on the measured heating power $u(P)$ is estimated assuming there is no correlation between the different parameters. It leads to equation (3) given in [19]. Therefore, the accuracy depends on both the estimation of the airflow rate $Q_{V}$ and of the temperature difference $\Delta T_{A}$. As a consequence, these two parameters have to be estimated carefully.

$$
u(P)=\sqrt{\sum\left(\frac{\partial P}{\partial x_{i}} \cdot \sigma\left(x_{i}\right)\right)^{2}}
$$

The heat exchanger is placed into a closed-loop wind tunnel with a constant airflow rate. Constant temperatures are applied at the inlet $\left(20^{\circ} \mathrm{C}\right.$ and $\left.45^{\circ} \mathrm{C}\right)$; the PCM will completely melt and solidify. The heating power is estimated during the solidification of the PCM. To give a better characterisation of the heat exchanger, this experiment is repeated for 8 different airflow rates, ranging from 300 to $900 \mathrm{~m}^{3} \cdot \mathrm{h}^{-1}$.

In the first part of the section, the experimental facility and the instrumentation are presented. Second, both temperature and airflow measurements are discussed for the lowest and the highest airflow rates. Finally, pressure drop measurements are detailed.

\subsection{Description of the air-supply system}

The experimental facility includes a complete HVAC system on the bottom part, and a testing cavity on the top part. The heat exchanger is placed in the testing cavity (Figure 4 and Figure 5): it is $2.5 \mathrm{~m}$ long and its section is $1 \mathrm{~m} \times 1 \mathrm{~m}$. In order to control the airflow rate inside the exchanger, both an upstream and a downstream section are added.

The upstream section is made of two parts and its overall length is $1 \mathrm{~m}$. In the first part, the cross-section is gradually reduced to the targeted cross-section (slope: 309 . In the second part, the cross-section re mains constant so an established airflow can be obtained. The downstream section is a $0.4 \mathrm{~m}$ long element with a constant cross-section in order to produce a uniform airflow. This allows achieving temperature measurements at the outlet of the exchanger.

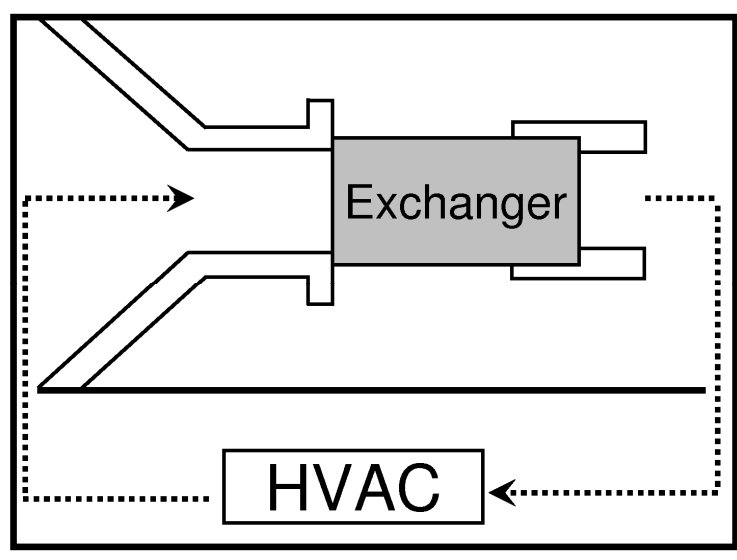

Figure 5: Scheme of the exchanger installed in the air-supply system

\subsection{Instrumentation}

First, the temperature difference is measured by the mean of 5 differential thermocouples fixed on nylon 
ropes in the upstream and in the downstream sections. Their positions are given in Figure 6 . These thermocouples were all calibrated in laboratory and their uncertainty is $\pm 0.3^{\circ} \mathrm{C}$. Three T-type thermocouples are added in the downstream section to measure the absolute air temperature.

The second key parameter in the heating power calculation is the airflow rate, which is monitored by the airsupply system. However, air leakages can happen, which may result in a lower airflow rate. Consequently, the heat exchanger and its setting within the experimental facility are designed in order to be as airtight as possible:

- Fastening techniques are preferred to drilling techniques to gather the different part of the prototype;

- The exchanger is tightened on the downstream section: aluminium corners are used to increase the contact surface (see Figure 3) and a rubber strip with identical dimensions is screwed onto (not visible in Figure 3). Two fastening straps are passing through the aluminium rails, then wrapped around the downstream section and stretched;

- Aluminium tape is used to enhance the sealing for both the upstream and the downstream section.

Still, leakages are happening and have to be taken into account. A unidirectional hot wire anemometer is set inside the upstream section in order to monitor the air velocity. It is sensitive to air speeds ranging from 0.05 to $2.50 \mathrm{~m} . \mathrm{s}^{-1}$ but not to the airflow direction. Preliminary tests are described in the next section.

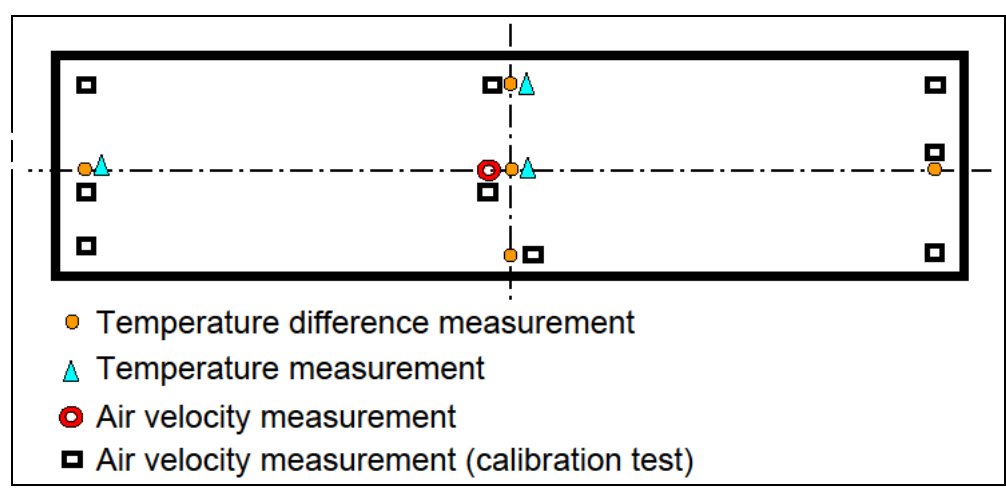

Figure 6: Position of the sensors installed in the upstream section ( $0.1 \mathrm{~m}$ away from the heat exchanger)

Other measurements are achieved to give a much complete understanding of the heat exchanger behaviour:

- A pressure difference device is connected to both the upstream and the downstream sections, close to the position of the temperature sensors and allows measuring the pressure difference.

- 32 thermocouples are used to measure temperatures at various locations inside the heat exchanger. For the sake of clarity, only three of them will be discussed. They are located directly in the container placed in the middle of the exchanger.

The number and accuracy of the sensors are summarized in Table 2.

Table 2: Description of the instrumentation

\begin{tabular}{lll}
\hline Physical parameter & Number & Accuracy \\
\hline Temperature difference $\left({ }^{\circ} \mathrm{C}\right)$ & 5 & \pm 0.3 \\
Air velocity $\left(\mathrm{m} \cdot \mathrm{s}^{-1}\right)$ & 1 & \pm 0.08 \\
Pressure difference $(\mathrm{Pa})$ & 1 & $\pm 0.5 \%$ of the value \\
Temperature $\left({ }^{\circ} \mathrm{C}\right)$ & 32 & \pm 0.5 \\
\hline
\end{tabular}

\subsection{Estimation of the global airflow rate}

The hot-wire anemometer is used to measure the air velocity in the upstream section when the heat exchanger is not installed. It is moved successively at nine different locations (see Figure 6). These measurements are achieved for two airflow rates $\left(300\right.$ and $\left.900 \mathrm{~m}^{3} \cdot \mathrm{h}^{-1}\right)$.

Besides, commercial CFD software STAR CCM is used to simulate the airflow in the upstream section. The air volume is meshed with an unstructured mesh containing more than 500,000 polyhedral cells. This mesh is refined close to the sidings, so the $0.01 \mathrm{~m}$ boundary layer is composed of 10 cells. The boundary conditions are:

- A homogeneous airflow at the inlet; 
- A zero-pressure condition at the outlet;

- Adiabatic wall condition for other boundaries.

Reynolds number is calculated in the cross-section located $0.1 \mathrm{~m}$ before the heat exchanger (the exchanger is not simulated); its value is higher than $10^{4}$ for velocities measured at $300 \mathrm{~m}^{3} \cdot \mathrm{h}^{-1}$, which means the airflow is turbulent. Therefore, a classical k-epsilon turbulence model is selected. Figure 7 presents the velocity profiles computed at middle-height in the cross-section where the sensors are installed.

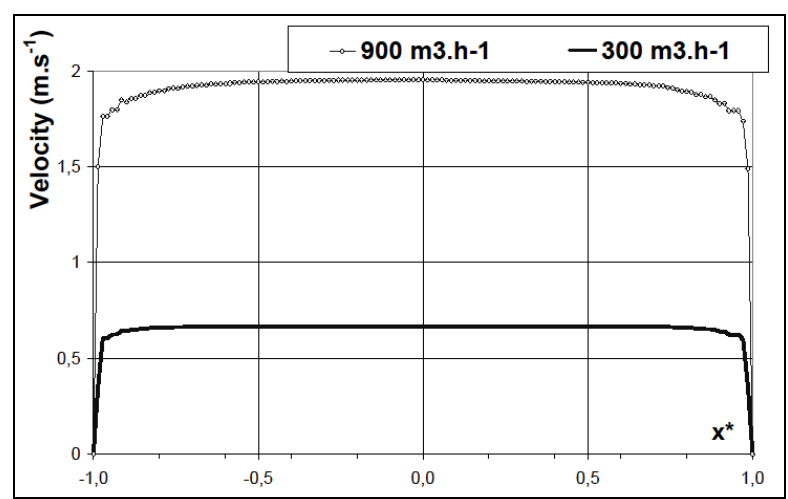

Figure 7: Velocity profiles computed with commercial CFD software for $300 \mathrm{~m}^{3} \cdot \mathrm{h}^{-1}$ and $900 \mathrm{~m}^{3} \cdot \mathrm{h}^{-1}$

First, these results show that the design of the upstream section allows obtaining an established flow. This is very convenient as the global airflow rate can be estimated from few measurements. Second, the comparison with airflow measurements showed that simulation results were consistently higher than measured velocities (the average difference is $9 \%$ ), which can be the consequence of leakages.

About the heating power calculation, it is assumed the leakages are resulting in a uniform decrease of the air velocity $(\Delta v=9 \%)$, and so as for the airflow rate. Consequently, the airflow rate can be estimated from a single air velocity measurement as presented in equation 4 . The coefficient $\mathrm{K}$ represents the ratio of the velocity measured in the middle the cross section to the average velocity $(K=0.89)$. A similar approach is presented in [18] and leads to values ranging from 0.6 to 0.9 , depending on the duct geometry and on the airflow rate.

$$
Q_{V}=v_{\text {Meas }} \cdot S \cdot K \cdot(1-\overline{\Delta v})
$$

\subsection{Pressure drop measurements}

Pressure drop is measured during the experiments: it rises up to $93 \pm 3 \mathrm{~Pa}$ at $900 \mathrm{~m}^{3} \cdot \mathrm{h}^{-1}$ and drops down to $26 \pm 2 \mathrm{~Pa}$ and $300 \mathrm{~m}^{3} \cdot \mathrm{h}^{-1}$. Results are plotted against the measured airflow rate computed with equation 4 in Figure 8. Finally, the airflow rate is related to pressure difference by a power law:

$$
\dot{Q}_{V}=C . \Delta p^{n}
$$

The fitted values are $C=22.518 \mathrm{~m}^{3} \cdot \mathrm{s}^{-1} \cdot \mathrm{Pa}^{-1}$ and $\mathrm{n}=0.8148$. A very good agreement is obtained: $91 \%$ of the measurements are included in the $\pm 3 \%$ range. Somehow, this gives confidence in the airflow rate calculation. These results can be used to design the integration of the heat exchanger in the ventilation network and calculate the related energy increase. 


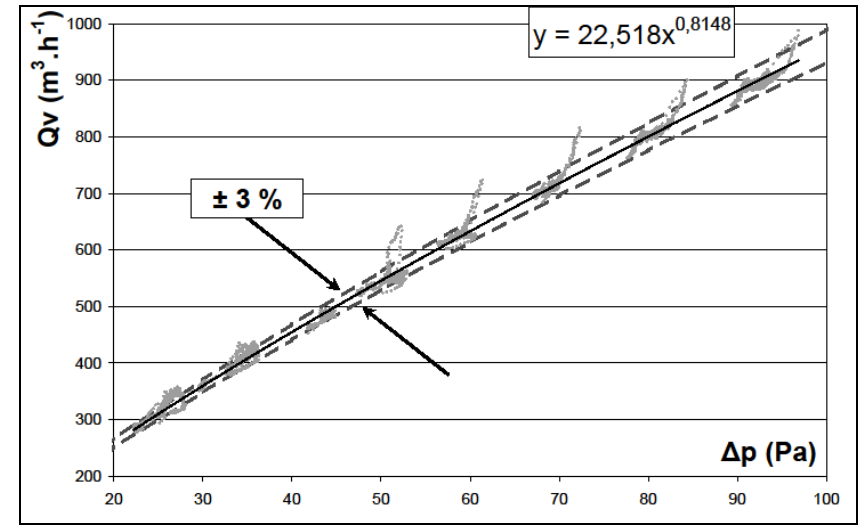

Figure 8: Pressure drop measurements for the experiments and fitted power law

\subsection{Temperature measurements within the PCM during solidification}

Temperature measurements in the PCM during the solidification at 300 and $900 \mathrm{~m}^{3} \cdot \mathrm{h}^{-1}$ are presented in Figure 9. Two sensors are located $0.1 \mathrm{~m}$ away from the inlet and the outlet and the third one is located at middle-length $(0.5 \mathrm{~m})$. The time reference $(\mathrm{t}=0 \mathrm{~h})$ corresponds to the airflow temperature change at the inlet.
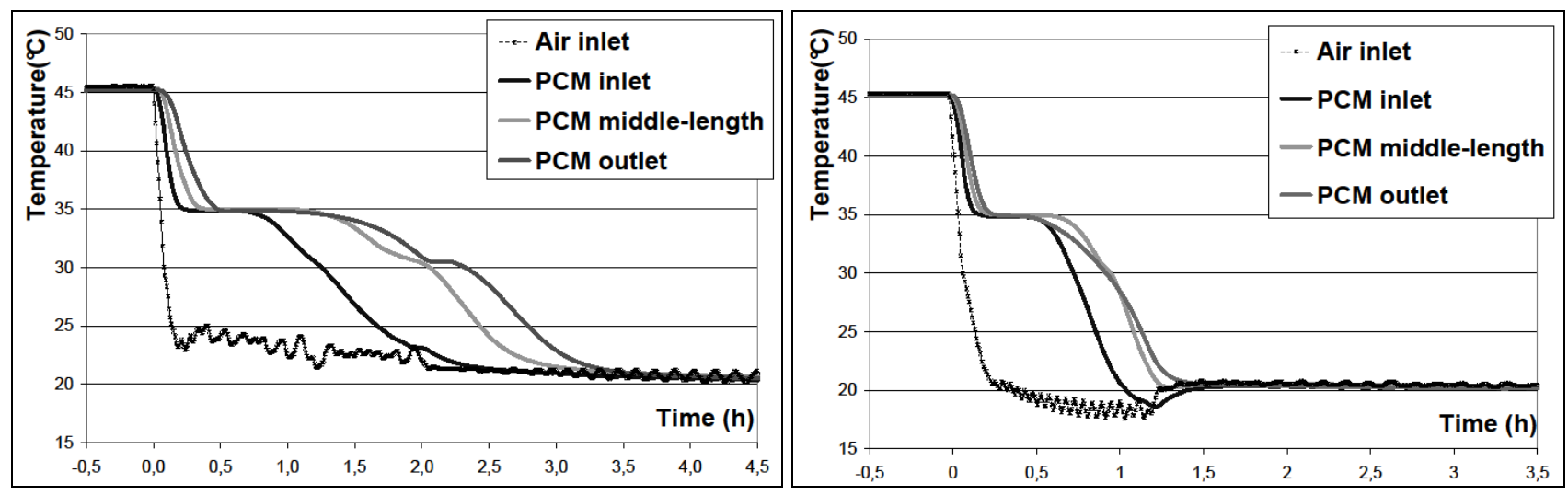

Figure 9: Temperature measurements during the solidification period at $300 \mathrm{~m}^{3} \cdot \mathrm{h}^{-1}$ (left) and $900 \mathrm{~m}^{3} \cdot \mathrm{h}^{-1}$ (right)

First, the temperature change at the inlet is not immediate. This results from the regulation of the closed loop system. Still, temperature measurements achieved directly in the PCM show a regular behaviour. Moreover, the temperature drop from $45^{\circ} \mathrm{C}$ to $20^{\circ} \mathrm{C}$ is rather quick and should not affect significantly the study of the heating power.

After a quick decrease from 45 to $35^{\circ} \mathrm{C}$, a stable-temperature-period is observed in the material. It lasts $18 \mathrm{~min}$ at $900 \mathrm{~m}^{3} \cdot \mathrm{h}^{-1}$ and up to $45 \mathrm{~min}$ at $300 \mathrm{~m}^{3} \cdot \mathrm{h}^{-1}$. Then, temperature starts to decrease again. At $300 \mathrm{~m}^{3} \cdot \mathrm{h}^{-1}$, a second stable-temperature-period is observed at $30.5^{\circ} \mathrm{C}$, which indicates that the solidification of the material is ongoing.

Finally, measured temperatures in the PCM at $900 \mathrm{~m}^{3} \cdot \mathrm{h}^{-1}$ are equal to the inlet temperature $1 \mathrm{~h} 30 \mathrm{~min}$ after the temperature change, meaning the heat release is finished. Therefore, it is obvious that the heat exchanger does not release $1 \mathrm{kWh}$ during $2 \mathrm{~h}$ for this experiment. However, at $300 \mathrm{~m}^{3} \cdot \mathrm{h}^{-1}$, the heat release is not complete two hours after the temperature change.

\subsection{Temperature difference measurements during solidification}

Temperature difference between the inlet and the outlet of the heat exchanger are presented in Figure 10. 

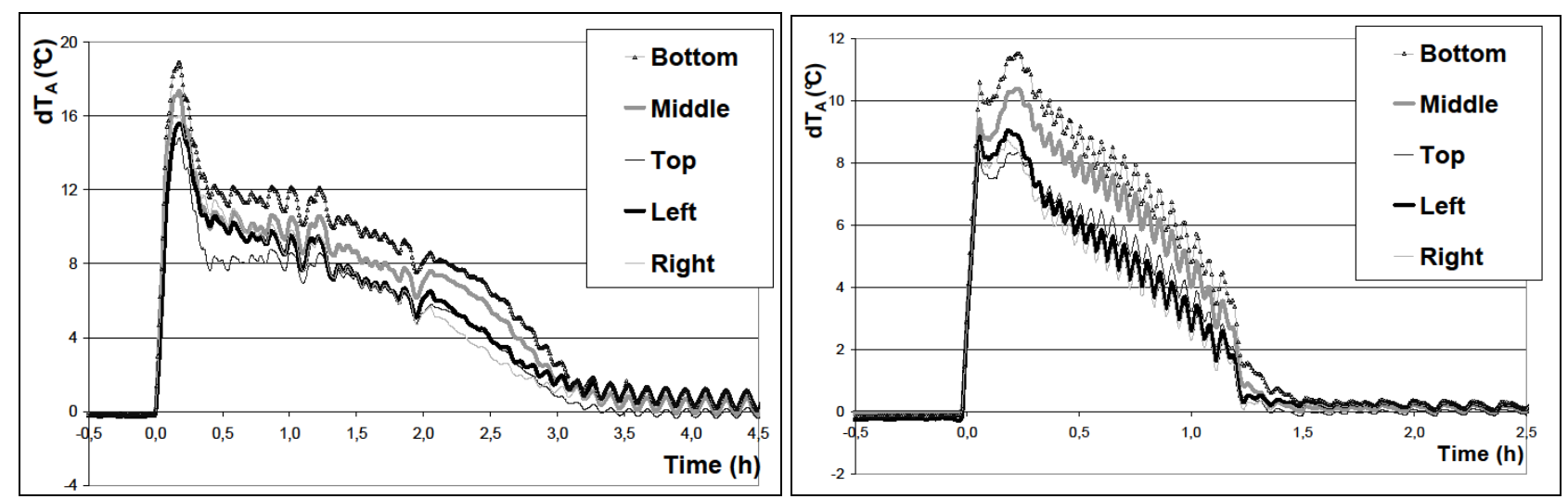

Figure 10: Temperature difference measurement during solidification at $300 \mathrm{~m}^{3} \cdot \mathrm{h}^{-1}$ (left) and $900 \mathrm{~m}^{3} \cdot \mathrm{h}^{-1}$ (right)

The highest temperature differences are obtained at the beginning of the experiment and remain constant for about $15 \mathrm{~min}$. Then, it decreases rather regularly to zero.

The temperature difference is not homogeneous over the cross-sections; the observed difference rises up to $4^{\circ} \mathrm{C}$ and the standard deviation is $1.3^{\circ} \mathrm{C}$ for the two experiments. Lower values are measured close to the sides while the highest values are measured at the bottom. These differences cannot be easily explained. For example, the standard deviation is lower than $0.1^{\circ} \mathrm{C}$ when the exchanger is neither storing nor releasing heat. Consequently, lower temperature differences measured close to the sides cannot be explained by a defective insulation of the exchanger. On the other hand, observed differences could be the consequence of non-uniform velocities over the cross-section or a non-uniform solidification over the heat exchanger height.

\section{RESULTS AND DISCUSSION}

\subsection{Estimation of the heating power and of the cumulative energy}

The heating power $P$ is calculated as presented in equation 1. The airflow rate $Q_{V}$ is calculated as presented in equation 4 and the temperature difference $\Delta \mathrm{T}_{\mathrm{A}}$ is the average value of the 5 measurements. Results are presented in Figure 11. For the sake of clarity, only few measurements are plotted because of the quick variation of the temperature difference (Figure 10).

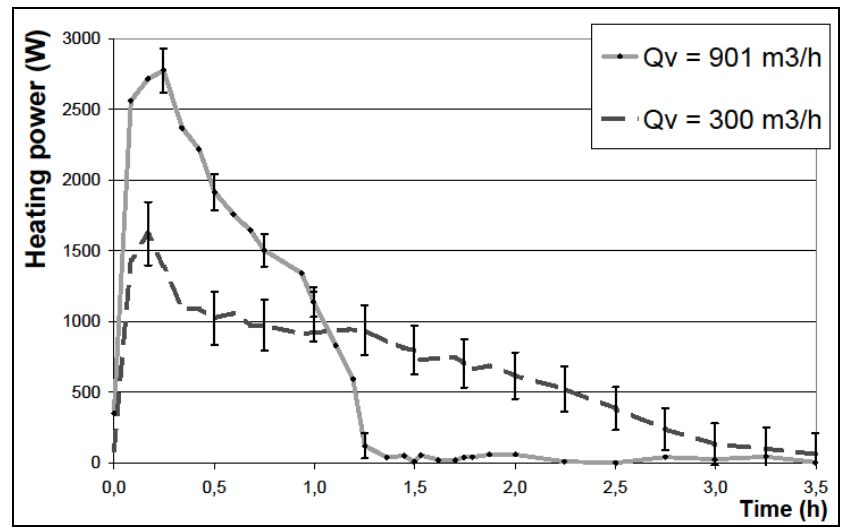

Figure 11: Measured heating power after the temperature change (from 45 to $20^{\circ} \mathrm{C}$ )

As the airflow rate remains constant over a single experiment, the heating power follows closely the measured temperature difference (Figure 10). At $900 \mathrm{~m}^{3} \cdot \mathrm{h}^{-1}$, the heating power rises quickly to $2770 \pm 157 \mathrm{~W}$ for $15 \mathrm{~min}$, then decreases regularly to reach $500 \pm 95 \mathrm{~W}$ at $1 \mathrm{~h} 15 \mathrm{~min}$. At $300 \mathrm{~m}^{3} \cdot \mathrm{h}^{-1}$, the maximum heating power is lower $(1620 \pm 225 \mathrm{~W})$ because of the lower airflow rate. It reaches $1025 \pm 187 \mathrm{~W}$ at $30 \mathrm{~min}$. Still it remains higher than $522 \pm 157 \mathrm{~W}$ during $2 \mathrm{~h} 15 \mathrm{~min}$. Consequently, the initial goal (obtaining a minimum $1 \mathrm{~kW}$ heating power during 2 hours) is not reached for both cases.

The heating power is integrated over the heat release period (measurements with a period of $1 \mathrm{mn}$ were used 
for this calculation). This represents the cumulative heat released by the heat exchanger. The uncertainty is estimated using the approach presented in (3) and results are presented in Figure 12 for airflow rates tested.
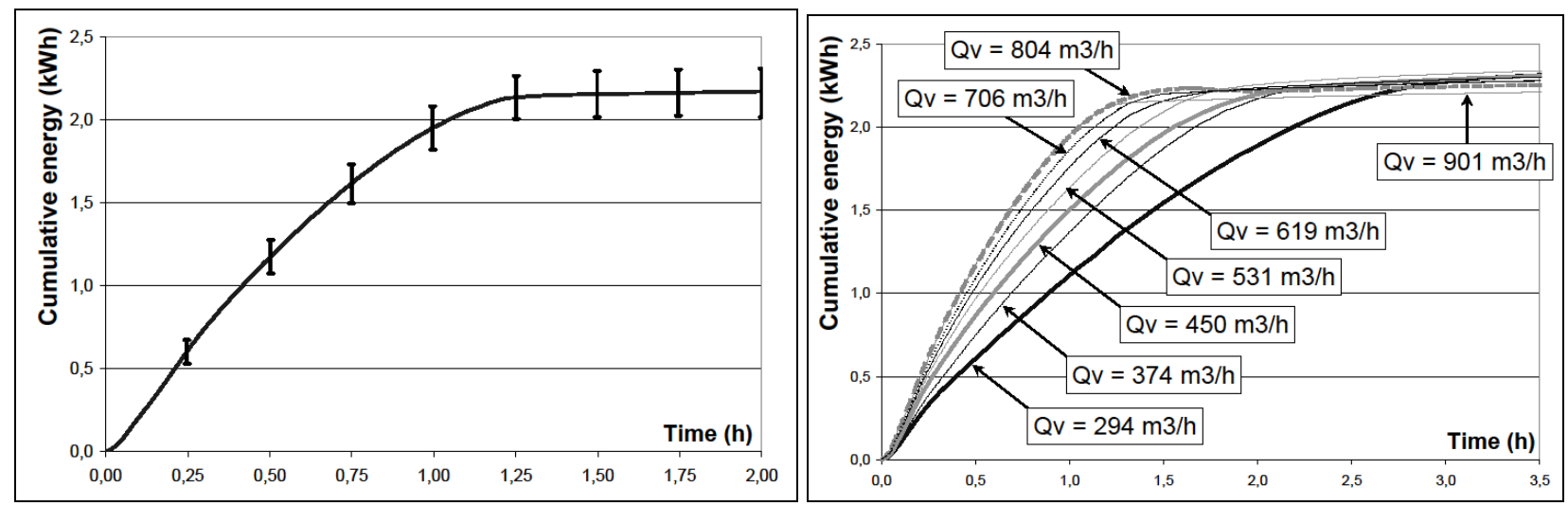

Figure 12: Cumulative energy released by the system after the temperature change from 45 to $20^{\circ} \mathrm{C}$ for $900 \mathrm{~m}^{3} \cdot \mathrm{h}^{-1}$ (left) and for the airflow rates tested (right)

First, the final value of the cumulative energy is almost the same for each experiment: the average value is $2.34 \mathrm{kWh}$ and the standard deviation is $0.07 \mathrm{kWh}$. This means the exchanger has stored enough energy to meet the heating demand.

Second, the standard deviation is twice lower than the measurement uncertainty $( \pm 0.15 \mathrm{kWh})$ and the calculated cumulative energy varies little with the airflow rate. This means the methodology and the instrumentation are relevant. Still, it is observed the computed total energy is slowly decreasing as tests are conducted (from the lowest to the highest airflow rate). This is the direct consequence from PCM leakages happening at the sidings of the containers; almost $0.8 \mathrm{~kg}$ of PCM was collected from leakages ( $3 \%$ of the total mass). The impact of these mass losses is not influencing in the discussion of the results. If the integration of such an exchanger in a real building was considered, this would become a major issue.

Finally, it is obvious that the heat release is faster at a higher airflow rate. However, results are nearly the same for the highest airflow rates $\left(804\right.$ and $\left.901 \mathrm{~m}^{3} \cdot \mathrm{h}^{-1}\right)$, which means an asymptotic behaviour has been reached.

\subsection{General behaviour}

To give an idea of the general heat exchanger behaviour, it is convenient to use dimensionless numbers. Here, the idea is to show the impact of an increasing airflow rate on the dynamic behaviour of the heat exchanger. Therefore, it is relevant to use the Fourier and the Stanton numbers as presented in equations 6 . The Stanton number measures the ration of the heat transferred into a fluid by convection to the thermal capacity of the fluid. The Fourier number characterizes the ration of the diffusive transport rate (by conduction) to the storage rate.

$$
\begin{aligned}
& F o=\frac{\lambda_{P C M}}{\rho_{P C M} \cdot C_{P, P C M}} \cdot \frac{t_{r}}{e_{P C M}^{2}} \\
& S t=\frac{h_{c}}{v_{A} \cdot \rho_{A} \cdot C_{P, A}}
\end{aligned}
$$

For the Stanton number calculation, the convective heat transfer coefficient $h_{c}$ has to be estimated. Here, it is determined based on the geometric considerations presented in [20]. Because of the cooling fins, the airflow rate between two containers is laminar for each airflow rate. Therefore, the convective heat transfer coefficient is constant with a value of $h_{c}=37 \mathrm{~W} \cdot \mathrm{m}^{-2} \cdot \mathrm{K}^{-1}$. As a result, the Stanton number variation depends only on the air velocity.

Fourier number is computed for the second half of the heat release, that is to say when the liquid fraction is 
lower than 0.5. In this case, it is assumed that the material properties for the solid state (see Table 1) are representative of the whole material. Heat transfer is assumed to be symmetric in a single container, so the characteristic length $e$ is equal to half of the total thickness $(e=0.009 \mathrm{~m})$. Finally, $t_{r}$ is selected to correspond to a given percentage of the total energy released. Fourier number is plotted against the inverse value of the Stanton number in Figure 13.

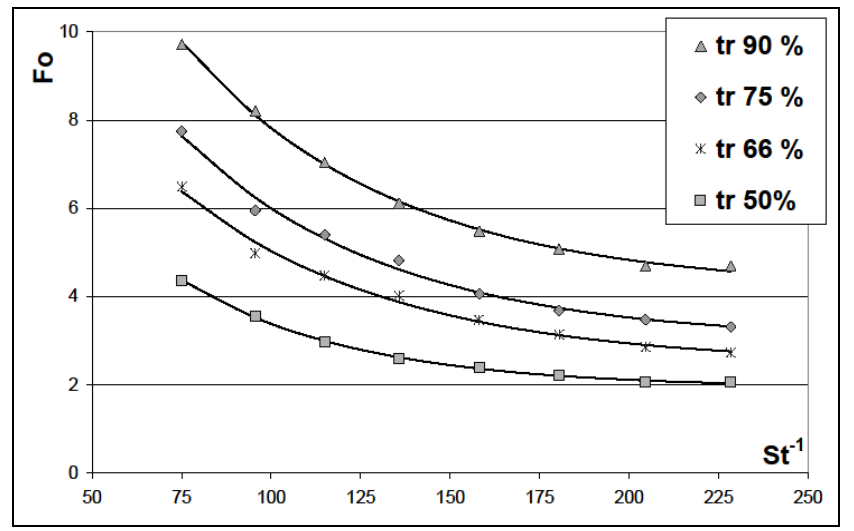

Figure 13: Comparison of Fourier and Stanton numbers for different percentage of heat release

The Fourier number is decreasing when the inverse Stanton number is increasing, meaning that a higher airflow rate is accelerating the heat release. An asymptotic behaviour is observed when the inverse Stanton number is higher than 200. A very good agreement is obtained between measurements and a general exponential equation 7. The fitted values of coefficients A1, A2 and A3 are presented in Table 3.

$$
F O=A_{1}+A_{2} \cdot \exp { }^{\left(A_{3} \cdot S t^{-1}\right)}
$$

Table 3: Coefficient values used in (8) fitted with the measurements

\begin{tabular}{lllll}
\hline & $\operatorname{tr}_{50 \%}$ & $\operatorname{tr}_{66 \%}$ & $\operatorname{tr}_{75 \%}$ & $\operatorname{tr} 90 \%$ \\
\hline A1 & $2,39 \mathrm{E}+00$ & $3,05 \mathrm{E}+00$ & $3,71 \mathrm{E}+00$ & $5,16 \mathrm{E}+00$ \\
$\mathrm{~A} 2$ & $1,43 \mathrm{E}+01$ & $1,72 \mathrm{E}+01$ & $2,12 \mathrm{E}+01$ & $2,49 \mathrm{E}+01$ \\
A3 & $-2,07 \mathrm{E}-02$ & $-1,68 \mathrm{E}-02$ & $-1,73 \mathrm{E}-02$ & $-1,70 \mathrm{E}-02$ \\
\hline
\end{tabular}

\subsection{Outlook}

Although PCM solidification is neither homogeneous nor easy to predict, the global behaviour of the heat exchanger is rather simple. This is an interesting result for numerical modelling purposes as this allows considering a simplified approach. Furthermore, measurements and geometry details presented in this paper are suitable with the validation of numerical models (similar measurements are used in [17]). Once validated, the model could be used to optimise the heat exchanger: this could help with reaching the initial objective (obtaining a $1 \mathrm{~kW}$ heating power during 2 hours).

However, using a constant airflow rate does not seem to be a suitable solution. Instead, a variable airflow rates should be considered. However, it should be kept in mind that this experimental study has been achieved for one single cooling fins geometry. Cooling fins can be used to modify the behaviour of the heat exchanger. Indeed, this element has several impacts:

- Heat transfer is increased because of the increased surface;

- The pressure loss is increased, which is a major issue in the design of a ventilation network;

- The airflow is laminar in this case, because of the small dimensions of the channels. It will become turbulent for larger channels, which will affect both the pressure loss and heat transfer. Also, this represents a limit in the validation of numerical models.

Therefore, it sounds promising to study much in detail the airflow rate management. 


\section{CONCLUSION}

In this paper, a heat exchanger containing more than $27 \mathrm{~kg}$ of PCM is presented and tested. It is designed to store enough energy to replace a $1 \mathrm{~kW}$ heat pump during 2 hours. The exchanger is placed within an air-supply system used to produce a constant airflow rate with temperature changes.

The main objective of the experimental tests is to determine the heating power during heat release. For this reason, earliest tests are conducted to ensure accurate estimations of both the airflow rate and temperature differences. The experimental set-up allows the evaluation of the energy stored/released in the system with an accuracy of $6 \%$. But, the initial objective could not be obtained for constant airflow rates varying from 300 to $900 \mathrm{~m}^{3} \cdot \mathrm{h}^{-1}$. However, the energy stored and released is higher than $2 \mathrm{kWh}$. Then, An optimization of the heat transfers is necessary to reach the objectives.

Although quick and non-homogeneous heat transfer is observable within the PCM (for example natural convection may occur), the global behaviour of the heat exchanger is rather simple. Therefore, an exponential relationship between the Fourier and the Stanton numbers could be fitted. This indicates considering a simplified numerical model is relevant for further work. Then, it could be used to optimise the current prototype and reach the initial objective, with using a variable airflow rate and other designs of cooling fins for example. The data presented in this paper will also be used to validate a numerical modelling of a PCM to air heat exchanger.

\section{ACKNOWLEDGMENTS}

This work has been possible with the support of the French ANR project STOCKAIR2 with the reference: ANR-2010-STKE-010.

\section{REFERENCES}

[1] H. Mehling, L. Cabeza, Heat and Cold Storage with PCM: An up to Date Introduction Into Basics and Applications, Heat and Mass Transfer, Springer Limited, 2008, London.

[2] V.V. Tyagi, D. Buddhi, Pcm thermal storage in buildings: a state of art, Renewable and Sustainable Energy Reviews 11 (6) (2007) 1146-1166.

[3] A. Waqas, Z.U. Din, Phase change material $(\mathrm{pcm})$ storage for free cooling of buildings: a review, Renewable and Sustainable Energy Reviews 18 (2013) 607-625.

[4] E. Halawa, W. Saman, Thermal performance analysis of a phase change thermal storage unit for space heating, Renewable Energy 36 (1) (2011) 259-264.

[5] V. Dubovsky, G. Ziskind, R. Letan, Analytical model of a pcm-air heat exchanger, Applied Thermal Engineering 31 (16) (2011) 3453-3462.

[6] S. Vakilaltojjar, W. Saman, Analysis and modelling of a phase change storage system for air conditioning applications, Applied Thermal Engineering 21 (3) (2001) 249-263.

[7] J. Borderon, J. Virgone, R. Cantin, F. Kuznik, Full-scale study of a building equipped with a multi-layer rack latent heat thermal energy storage system, HVAC\&R Research 17 (4) (2011) 566-576.

[8] B. Zalba, J.M. Marin, L.F. Cabeza, H. Mehling, Free-cooling of buildings with phase change materials, International Journal of Refrigeration 27 (8) (2004) 839-849.

[9] P. Dolado, A. Lazaro, J.M. Marin, B. Zalba, Characterization of melting and solidification in a real-scale pcm air heat exchanger: experimental results and empirical model, Renewable Energy 36 (11) (2011) 29062917.

[10] S. Vakilaltojjar, Phase Change Thermal Storage System for Space Heating and Cooling, University of South Australia, Adelaide, 2000 (Ph.D. thesis).

[11] P. Dolado, J. Mazo, A. Lazaro, J. Maria, B. Zalba, Experimental validation of a theoretical model: uncertainty propagation analysis to a pcm-air thermal energy storage unit, Energy and Buildings 45 (2012) 124-131. 
[12] E. Osterman, V. Tyagi, V. Butala, N. Rahim, U. Stritih, Review of pcm based cooling technologies for buildings, Energy and Buildings 49 (2012) 37-49.

[13] Lazaro A., Dolado P., Maran M.J., Zalba B., PCM air heat exchangers for free cooling application in buildings: Experimental results of two real-scale prototypes, Energy Conversion and Management 50 (3) 2009, p. $439-443$

[14] A. Mosaffa, C.I. Ferreira, F. Talati, M. Rosen, Thermal performance of a multiple pcm thermal storage unit for free cooling, Energy Conversion and Management 67 (2013) 1-7.

[15] J. Borderon, Intégration des matériaux à changement de phase comme système de régulation dynamique en rénovation thermique, ENTPE, Lyon, 2012 (Ph.D. thesis).

[16] Virgone J., Kindinis A. Peak power reduction using a PCM storage coupled with a heat pump in a ventilation system. Innostock 2012, Lleida, May 2012, 9p.

[17] Arzamendia Lopez J .P., Kuznik F., Baillis D., Virgone J., Numerical modelling and experimental validation of a PCM to air heat exchanger, Energy Buildings (2013), Energy and Building, Volume 64, September 2013, Pages 415-422

[18] Falk, J., Sandin, K., 2013. Ventilated rainscreen cladding: A study of the ventilation drying process. Building and Environment 60, 173-184.

[19] EURACHEM/CITAC. Quantifier les incertitudes dans les mesures analytiques, 2nd Ed., France. SLR Ellison (LGC-UK) - M ROSSLEIN (EMPA- Switerland) - A WILLIAMS (UK), 2000.

[20] Fundamentals of Heat and Mass Transfer, Incropera F.P., DeWitt D.P., 2002 